\title{
INFLUENCE OF GRAM-NEGATIVE STRAIN KLEBSIELLA OXYTOCA ON BIOCORROSION
}

\author{
CHITRA S ${ }^{1 *}$, ANAND B ${ }^{2}$
}

${ }^{1}$ Department of Chemistry, AMET University, Kanathur, Chennai, Tamil Nadu, India. ${ }^{2}$ Department of Chemistry, Sir Theagaraya College of Arts and Science, Chennai, Tamil Nadu, India. Email: chitrachem@gmail.com

Several studies of biofilms must accept that biofilms may develop in an enormous number of environments. This biofilm forms colonization on the solid surfaces by extracellular polysaccharides (EPSs) secreted by the microbial cells. The EPSs secreted by microbial cell stimulate corrosion in the engineered materials due to the presence of polyanionic neutral macromolecules. Many techniques have been described measuring and inhibiting microbiologically influenced corrosion; however, none has been accepted as an industry standard. This is because the risks posed to the marine biosphere due to the use of antifouling inhibitors. Recently, a large amount of literature has been edited on the influence of toxic biocides on nontargeted organisms in the marine environment are most likely. It has been shown that the modifications of antifouling inhibitors by the non-toxic drugs can reduce microbial adhesion and some disentangle effects toward the environment. Hence, in this paper, the inhibition effect of neomycin trisulfate on the Klebsiella oxytoca on mild steel corrosion has been investigated using weight loss measurement, electrochemical impedance spectroscopy, Fourier-transform infrared, and scanning electron microscopy (SEM). These studies have shown that neomycin trisulfate shows better inhibition toward the microbe. The agreement with the experimental data was also found to be satisfactory. Further, surface morphological examination through SEM confirms that the inhibitor inhibits the microbes by blocking the EPS.

Keywords: Biocorrosion, Extracellular polysaccharides, Non-toxic, Gram-negative strains, Drugs.

(C) 2018 The Authors. Published by Innovare Academic Sciences Pvt Ltd. This is an open access article under the CC BY license (http://creativecommons. org/licenses/by/4. 0/) DOI: http://dx.doi.org/10.22159/ajpcr.2018.v11i2.19431

\section{INTRODUCTION}

Biofilms could be deleterious to materials, when they induce corrosion. Microbiologically influenced corrosion (MIC) is a serious problem in a number of industries including power generation, petrochemical, pulp and paper, gas transmission, and shipbuilding [1]. As the microorganisms grow on substratum surfaces, they produce various metabolic by-products, which might promote deterioration of the underlying substratum [2]. These reactions refer to biocorrosion or MIC when the underlying substratum is a metal or metal alloy. The cell surface protects microbe and provides structural support. The difference between them is related to cell wall configuration and the great majority of microbial cell in the environment tend to be Gramnegative $[3,4]$. During adhesion process, Gram-negative bacterium will more attracted to a positively charged surface and vice versa. It has been shown that proteinaceous appendages including pili and flagella initiate the bacterial adhesion by establishing bridges between surface and cell wall [5]. This extracellular polysaccharides (EPSs) form the framework of microbial mats and are typically composed of polysaccharide, lipid, and protein in the form of heteropolymers. Consequently, with this communication, EPS is generally considered to be important in cementing bacterial cells together in biofilm structure [6]. Normally, EPS possesses anionic character mainly due to the high content of weak organic acids. The rate at which corrosion propagate is mainly depends on the weak acid produce by aerobic and anaerobic bacteria [7,8]. As with the literature review, the Halomonas subglaciescola, Pseudomonas aeruginosa, Klebsiella oxytoca, Bacillus subtilis, Serratia marcescens, Bacillus cereus, Acidithiobacillus ferrooxidans, and Staphylococcus epidermidis are the microbial communities which are dominant in degradation [9]. Hence, in the present study, we aimed at investing the effect of $K$. oxytoca which is present in organic pollutant rich areas like gasoline.

\section{EXPERIMENTAL APPROACH}

Preparation of test panels

The mild steel strips were cut into pieces of $5 \mathrm{~cm} \times 1 \mathrm{~cm}$ with the thickness $3 \mathrm{~mm}$ having the following composition (in percentage) $\%$
$\mathrm{C}=0.017 ; \mathrm{Si}=0.007 ; \mathrm{Mn}=0.196 ; \mathrm{S}=0.014 ; \mathrm{p}=0.009 ; \mathrm{Ni}=0.013 ; \mathrm{Mo}=0.015$; $\mathrm{Cr}=0.043$; and $\mathrm{Fe}=99.686$ was used. The metal samples were scratched with various grades of abrasive paper and cleaned with ethanol solution.<smiles>NC[C@H]1O[C@H](O[C@@H]2[C@@H](N)C[C@@H](N)[C@H](O)[C@H]2OC2O[C@H](CO)[C@@H](O[C@@H]3O[C@H](CN)[C@@H](O)[C@H](O)[C@H]3N)[C@H]2O)[C@H](N)[C@H](O)[C@@H]1O</smiles>

\section{Chemical and materials}

Heterocyclic compounds such as antibiotic (pharmaceutical drugs) can provide excellent inhibition. Neomycin trisulfate was purchased from Sigma Aldrich and used as an inhibitor. The molecular structure and other details are mentioned below. Double-distilled water was used throughout all the experiment.

\section{Neomycin trisulfate \\ - $\mathrm{C}_{23} \mathrm{H}_{46} \mathrm{~N}_{6} \mathrm{O}_{13} \cdot 3 \mathrm{H}_{2} \mathrm{SO}_{4}$ \\ - $\quad 908.9 \mathrm{~g} / \mathrm{mol}$.}

\section{Culture preparation}

The bacterial strains were used throughout the investigation. All the bacterial cultures were obtained from the microbial type culture collection, Institute of Microbial Technology, Chandigarh, India. The young bacterial broth cultures were prepared before the screening procedure.

Composition of growth medium

The nutrient agar is the frequent medium used for all bacterial isolation. 


\begin{tabular}{l}
\hline Composition $\mathbf{g} / \mathrm{ml}$ \\
\hline $0.5 \%$ peptone \\
$0.3 \%$ of yeast extract/beef extract \\
$1.5 \%$ solidified agar \\
$0.5 \%$ Nacl \\
Distilled water \\
\hline
\end{tabular}

\section{Preparation of inoculums}

Stock cultures were maintained $4^{\circ} \mathrm{C}$ on slopes of nutrient agar. Active cultures of the experiment were prepared by transferring a loopful of cells from the stock cultures to test tube of Muller-Hinton broth (MHB) for bacteria that were incubated without agitation for $24 \mathrm{~h}$ at $37^{\circ} \mathrm{C}$ and $25^{\circ} \mathrm{C}$, respectively. The cultures were diluted with fresh MHB to achieve optical densities corresponding to $2.0 \times 10^{6}$ colony-forming units $/ \mathrm{ml}$ for bacteria [10-12]

\section{Inhibitor susceptibility test}

The method (Bauer et al.,) was used to screen the antimicrobial activity. In vitro antimicrobial activity was screened using Muller-Hinton Agar (MHA) obtained from Hi-media (Mumbai). The MHA plates were prepared by pouring $15 \mathrm{ml}$ of molten media into sterile Petriplates. The plates were allowed to solidify for $5 \mathrm{~min}, 0.1 \%$ inoculums suspension was swabbed uniformly, and the inoculums were allowed to dry for

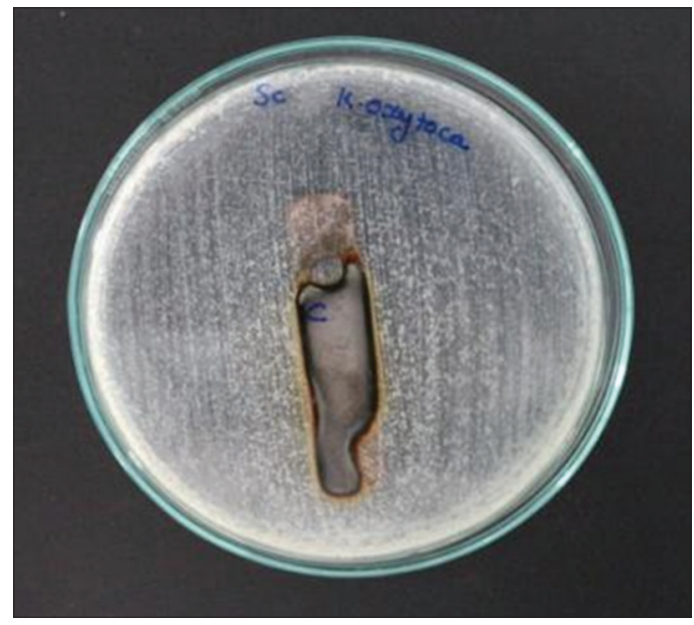

Fig. 1: Test panel after 10 days exposure without the inhibitor

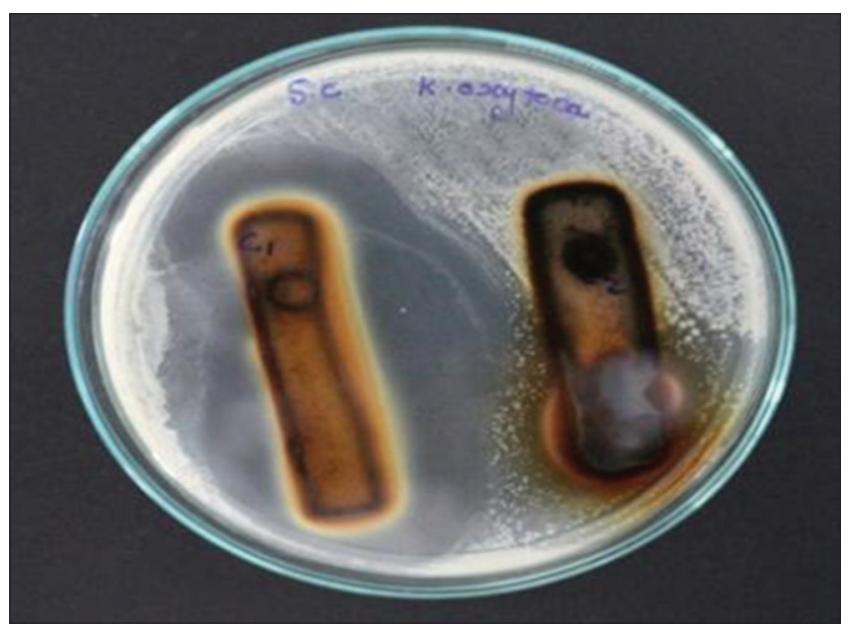

Fig. 2: Test panel after 10 days exposure to inhibitor
$5 \mathrm{~min}$. The metals were placed on the surface of the medium, the extract was allowed to diffuse for $5 \mathrm{~min}$, and the plates were kept in incubation at $37^{\circ} \mathrm{C}$ for $24 \mathrm{~h}$. At the end of incubation, inhibition zones formed around the disc were measured with a transparent ruler in millimeter. The standard disc is chloramphenicol.

\section{Sampling and biofilm}

The Gram-negative strain K. oxytoca was used for this study. To obtain a robust layer of mucilage adhering to a metal sample, the metal samples were placed in a Petri dish containing the culture with the exposure of 10 days (Figs. 1 and 2 ).

The metal samples were taken away from the culture media and the biofilm on the surface was removed by razor blade [13]. After the removal, the metals were washed with acetone and the final weight was used to calculate the corrosion rate.

Table 1: Data of weight loss measure in sterile and inoculated medium

\begin{tabular}{llll}
\hline Medium & \multicolumn{3}{l}{ Exposure of 10 days } \\
\cline { 2 - 4 } & $\begin{array}{l}\text { Corrosion } \\
\text { Rate }\end{array}$ & $\boldsymbol{\theta}$ & $\begin{array}{l}\text { Inhibition } \\
\text { Efficiency }\end{array}$ \\
\hline Strain+test coupon & 91.671 & - & - \\
Strain+test coupon+Inhibitor & 23.457 & 0.7120 & 71.2 \\
\hline
\end{tabular}

Table 2: Weight loss of various concentrations of inhibitor in $1 \mathrm{M}$ $\mathrm{NaCl}$ at room temperature

\begin{tabular}{lll}
\hline Inhibitor concentration & Corrosion rate & IE\% \\
\hline Blank & 27.7 & - \\
$1^{*} 10^{-5}$ & 24.1 & 13.0 \\
$2^{*} 10^{-5}$ & 18.7 & 32.4 \\
$3^{*} 10^{-5}$ & 15.8 & 42.9 \\
$4^{*} 10^{-5}$ & 10.9 & 60.7 \\
$5^{*} 10^{-5}$ & 10.7 & 61.5 \\
$6^{*} 10^{-5}$ & 7.3 & 70.9 \\
$7^{*} 10^{-5}$ & 3.9 & 77.7 \\
\hline
\end{tabular}

Table 3: AC impedance parameters for corrosion of mild steel in sterile and inoculated medium

\begin{tabular}{|c|c|c|c|}
\hline \multirow[t]{2}{*}{ Medium } & \multicolumn{3}{|l|}{ Parameter } \\
\hline & Rct $\left(o h m\right.$ cm$\left.^{2}\right)$ & Cdl $\left(\mu \mathrm{F} \times 10^{-5}\right)$ & $\begin{array}{l}\text { Inhibition } \\
\text { efficiency (\%) }\end{array}$ \\
\hline $\begin{array}{l}\text { Strain+test } \\
\text { coupon }\end{array}$ & 12.60 & 309.48 & - \\
\hline $\begin{array}{l}\text { Strain+test } \\
\text { coupon+inhibitor }\end{array}$ & 46.50 & 296.46 & 79.94 \\
\hline
\end{tabular}

Table 4: AC impedance parameters for corrosion of mild steel in various concentrations of inhibitor

\begin{tabular}{|c|c|c|c|}
\hline $\begin{array}{l}\text { Inhibitor } \\
\text { concentration (M) }\end{array}$ & Rct $\left(\mathrm{ohm} \mathrm{cm}^{2}\right)$ & Cdl (ohm $\left.\mu \mathrm{F} / \mathrm{cm}^{2}\right)$ & IE \% \\
\hline Blank & 10.67 & 975.0 & - \\
\hline $1 * 10^{-5}$ & 28.1 & 582.4 & 62.02 \\
\hline $2 * 10^{-5}$ & 30.5 & 570.0 & 65.01 \\
\hline $3^{*} 10^{-5}$ & 37.2 & 559.8 & 71.31 \\
\hline $4^{*} 10^{-5}$ & 40.9 & 533.0 & 73.91 \\
\hline $5^{*} 10^{-5}$ & 45.3 & 517.9 & 76.44 \\
\hline $6^{*} 10^{-5}$ & 47.6 & 507.5 & 77.58 \\
\hline $7 * 10^{-5}$ & 59.8 & 480.2 & 82.15 \\
\hline
\end{tabular}




$$
\text { Corrosion rate }=\frac{534 * \text { Weight loss in grams }}{\mathrm{A}^{*} \mathrm{D}^{*} \mathrm{~T}}
$$

\section{Electrochemical impedance spectroscopy}

The electrochemical experiments were carried in a conventional three-electrode cell assembly. In three-electrode system test coupons of $1.0 \mathrm{~cm}^{2}$ areas exposed as working electrode, a high purity platinum sheet as a counter electrode and saturated calomel electrode was used as a reference electrode [14]. Experiments were carried out in electrochemical workstation model $600 \mathrm{D} / \mathrm{E}$ series in without and with the addition of an inhibitor, a stabilization period of $30 \mathrm{~min}$ was allowed, which is enough to attain stable OCP value.

\section{Surface analysis}

To analyze the surface of the test panel, first the test panels were immersed in $2 \mathrm{~h}$ in glutaraldehyde solution at $4^{\circ} \mathrm{C}$ to stick the bacterial culture to the surface. Second, the test panels were rinsed and dehydrated using acetone [15-18]. Then, the test panels were coated gold/platinum and studied with the scanning electron microscopy (SEM).

\section{RESULT AND DISCUSSION}

Weight loss of test panels

After 10 days of exposure, the test panels were weighed after taking out the corrosion products. Mass loss of the test panels exposed to the

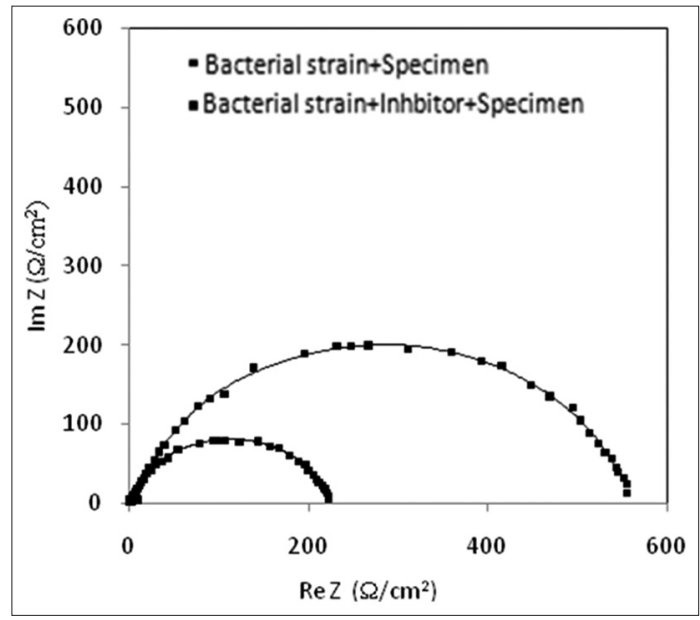

Fig. 3: Nyquist plots for mild steel specimen expose to bacterial strain with and without the inhibitor

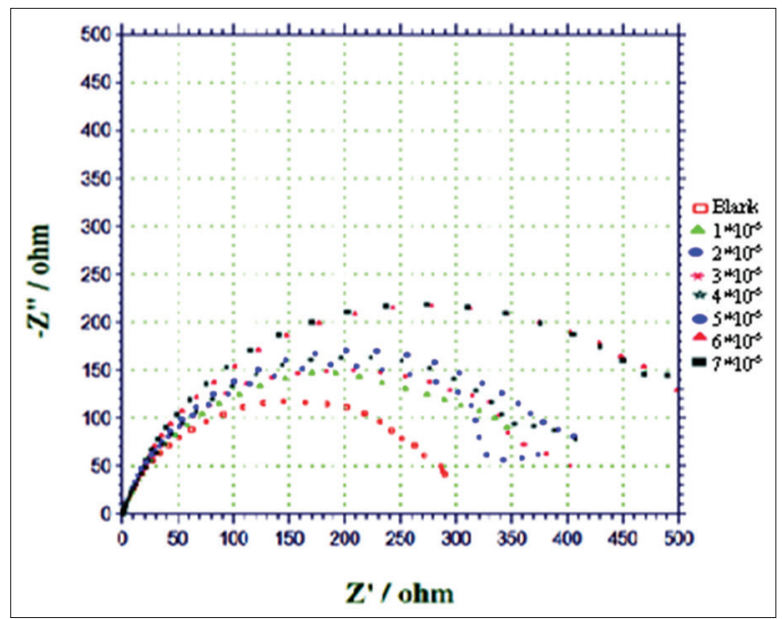

Fig. 4: Electrochemical impedance (Nyquist) spectrum of mild steel in $1 \mathrm{M} \mathrm{NaCl}$ solution with and without various concentrations of inhibitor bacterial strain with and without the addition of the inhibitor is given in Table 1, respectively.

It is obvious that the inhibition efficiency of the inhibitor at a concentration of $7 * 10^{-5} \mathrm{M}$ was found to be $71.2 \%$. Furthermore, the inhibitor could significantly reduce the mass loss in the presence of bacterial culture [19]. The mass loss of the mild steel exposed to bacterial strain in the presence of inhibitor is lower compared to the specimen without the inhibitor [20].

From Table 2, it is clear that the corrosion rate was decreased with increasing concentration of inhibitor and inhibition efficiency, increased with increasing the concentration of the inhibitor. However, when comparing the inhibition efficiency of the drug in general corrosion and microbial growth inhibition, it was found that the inhibition capability of drug is more in general corrosion.

\section{Electrochemical impedance spectroscopy}

Electrochemical impedance spectra of mild steel in general and microbial corrosion with the presence and absence of neomycin tri sulphate were depicted in the Nyquist plot as shown in the Figs. 3 and 4.

Impedance parameter obtained from Nyquist plot is given in Tables 3 and 4. It was observed that the Nyquist plot shows capacitive loop, the semicircle with high frequency owing to charge transfer resistance for relaxation of electrical double layer, and the diameter of semicircle increases in the presence of inhibitor [21-23].

In Tables 3 and 4, the Cdl values were reduced with an increase in the concentrations of inhibitor. This is due to the formation of defending film on the surface of mild steel by the addition of inhibitor, resulting in raising the inhibition efficiency. The EIS parameters such as Rct and $\mathrm{Cdl}$ are given in Tables 3 and 4. The values of IE\% acquired from the charge transfer resistances are calculated according to the following equation 1:

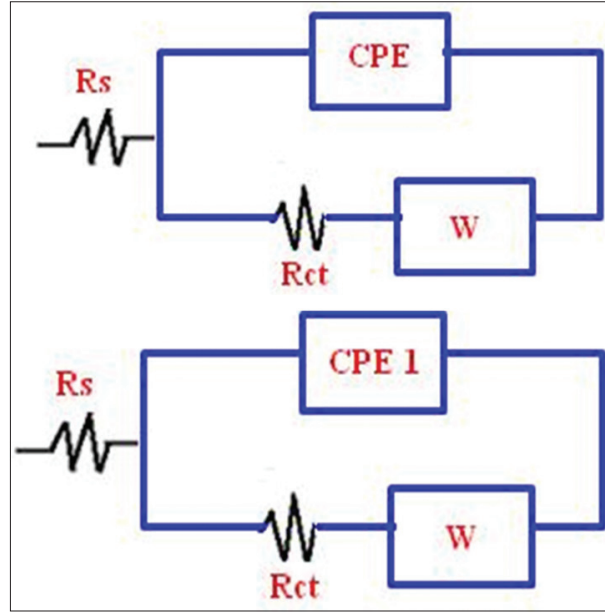

Fig 5: (a and b) Equivalent circuit for test panel in the presence and absence of inhibitor in sterile medium after 10 days exposure
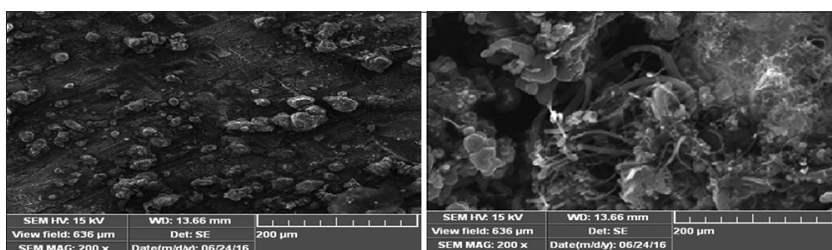

Fig. 6: (a) Test panel after 10 days exposure in the presence of bacterial strain with the inhibitor, (b) test panel after 10 days exposure in the presence of bacterial strain without the inhibitor 


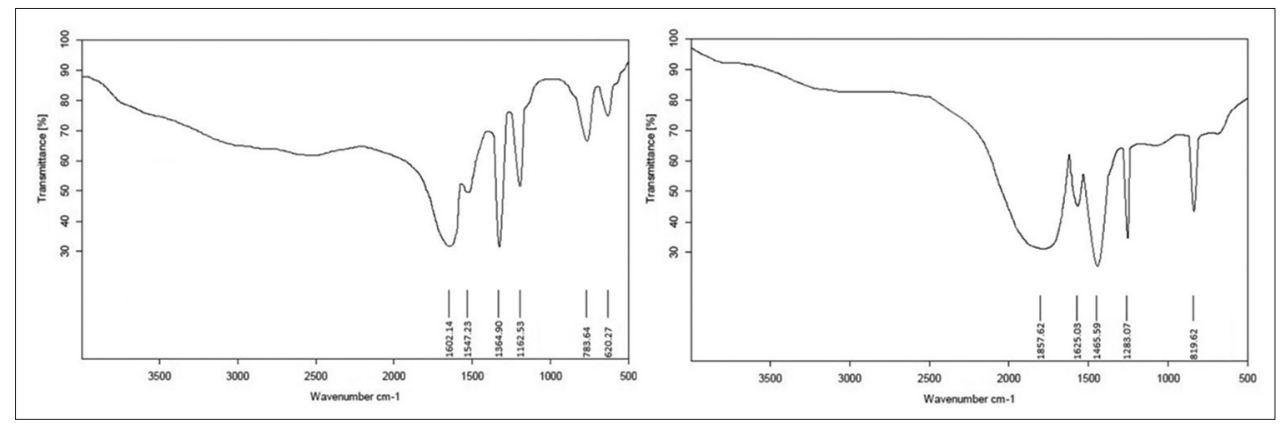

Fig. 7: (a) Fourier-transform infrared (FTIR) spectra of corrosion product of test coupon in the presence of sterile medium and Klebsiella oxytoca, (b) FTIR spectra of corrosion product of test coupon in the presence of $K$. oxytoca and inhibitor

$\operatorname{IE}(\%)=\left[\frac{\mathrm{R}_{\mathrm{ct}}^{\mathrm{i}}-\mathrm{R}_{\mathrm{ct}}^{\mathrm{o}}}{\mathrm{Ri}_{\mathrm{ct}}}\right] * 100$

Where and indicate the charge transfer resistance values in the presence and absence of inhibitor, respectively.

A simple Randle's equivalent circuit was set to fit the mechanism of the inhibitor with the charge transfer resistance (Rct), double layer capacitance (Cdl1), Cdl2, and medium resistance (Rs) as shown in Fig. 5a and b.

\section{Bacterial morphology on the test panel}

The photograph to validate the bond of the K.oxytoca in the presence and absence of inhibitor are given in the Fig. 6a and b.

There are many investigations about corrosion caused by biofilmforming bacteria, for example, Beech et al. [22] and Kielemoes et al. [23], and some about corrosion inhibition, for example, Chongdar et al. [24] and Zuo et al. [25].

Those researches indicate that biofilm-forming microorganism may cause corrosion or protective effects on metal surface, the effects possibly depending on the characteristic of microorganism [26].

\section{Fourier-transform infrared (FTIR) interpretation}

FTIR spectra are a vital technique to identify biofilms and their chemical changes in the presence of inhibitor. Through the balanced growth, the amide I and amide II band of C-O stretch at 1650,1540 , and $1084 \mathrm{~cm}^{-1}$ is due to the formation of protein films on test coupon as shown in Fig. 7a and $\mathrm{b}$. It is evident from Fig. 7 a that the most susceptible spectral region to the protein secondary structural components is the amide I band at $1625 \mathrm{~cm}^{-1}$, which is due roughly to the $\mathrm{C}=0$ stretch vibrations of the peptide linkages. The amide II band, in contrast, derives mainly from inplane $\mathrm{NH}$ bending and from the $\mathrm{CN}$ stretching vibration, showing much less protein conformational sensitivity. The signal range from 1200 to $900 \mathrm{~cm}^{-1}$ is due to polysaccharide production. The band at $819.62 \mathrm{~cm}^{-1}$ indicates the presence aromatic methane (strong) in the inhibitor.

\section{CONCLUSION}

In summary, this study provided an initial look of $K$. oxytoca on mild steel corrosion

1. The IE of antibiotic drugs neomycin trisulfate was found to show a good trend with weight-loss method and electrochemical impedance spectroscopy studies.

2. Comparing the inhibition efficiency, the inhibitor shows more effectiveness in general corrosion.

3. The morphological investigation also confirms that the inhibitor inhibits the mild steel corrosion of $K$. oxytoca only by blocking the EPS secreted by the microorganism.

\section{ACKNOWLEDGMENT}

The Authors wish to acknowledge the Alpha Omega Hi-tech Bio Research Centre for providing facilities for this work.

\section{AUTHOR'S CONTRIBUTION}

We certify that we have participated sufficiently in the work to take public responsibility.

1. S. Chitra (Study conception, design, acquisition of data and Drafting Manuscript)

2. Dr. B. Anand (Analysis and interpretation of data).

\section{CONFLICTS OF INTEREST}

we have no conflicts of interest to declare.

\section{REFERENCES}

1. Gentil V. Corrosão. $5^{\text {th }}$ ed. Rio de Janeiro, S.A.: Livros Técnicos e Científicos; 2007

2. Shi X, Xie N, Gong J. Recent progress in the research on microbially influenced corrosion: A bird's eye view through the engineering lens. Recent Pat Corros Sci 2011;1:118-31.

3. Ghali E. Corrosion Resistance of Aluminum and Magnesium Alloys: Understanding, Performance, and Testing. Canada: John Wiley \& Sons, Inc.; 2010.

4. Demadis KD, Mantzaridis C, Lykoudis P. Effects of structural differences on metallic corrosion inhibition by metalpolyphosphonate thin films. Ind Eng Chem 2006;45:7795-800.

5. Hansson CM. The impact of corrosion on society. Metall Mater Trans 2010:42:2952-62.

6. Geroge FH. Now is the Time. Cambridge: World Corrosion Organization; 2012.

7. Videla HA, Herrera LK, Edyvean RG. An Updated Overview of SRB Induced Corrosion and Protection of Carbon Steel. Paper No. 05488. Houston, TX: NACE International; 2005. p. 3-7.

8. O'toole GA, Kaplan B, Kolter R. Biofilm formation as microbial development. Ann Rev Microbiol 2000;54:49-79.

9. Beech WB. Biofilms on corroding materials. In: Lens P, Moran AP, Mahony T, Stoodly P, O'Flaherty V, editors. Biofilms in Medicine, Industry and Environmental Biotechnology-Characteristics, Analysis and Control. London: IWA Publishing Alliance House; 2003. p. $115-31$.

10. Beech WB. Corrosion of technical materials in the presence of biofilms-current understanding and state-of-the art methods of study. Int Biodeterior Biodegradation 2004;53:177-83.

11. Beech IB, Sunner JA, Hiraoka K. Microbe-surface interactions in biofouling and biocorrosion processes. Int Microbiol 2005;8:157-68.

12. Xavier JB, Picioreanu C, Van Loosdrecht MC. A general description of detachment for multidimensional modelling of biofilms. Biotechnol Bioeng 2005;91:651-69.

13. Hubert C, Nemati M, Jenneman G, Voordouw G. Corrosion risk associated with microbial souring control using nitrate or nitrite. Appl Microbiol Biotechnol 2005;68:272-82

14. González IN, Wang ET, Rez FR, Romero JM, Rodriguez CH. Characterization of bacterial community associated to biofilms of corroded oil pipelines from the southeast of Mexico. Anaerobe 2006;12:122-33

15. Videla HA. Prevention and control of biocorrosion. Int Biodeterior Biodegradation 2002;49:259-70

16. Videla HA, Herrera LK. Microbiologically influenced corrosion: Looking to the future. Int Microbiol 2005;8:169-80. 
17. Rajasekar A, Maruthamuthu S, Palaniswamy N, Rajendran A. Biodegradation of corrosion inhibitors and their influence on petroleum product pipeline. Microbiol Res 2007b;162:355-68.

18. Beech IB, Sunner J. Biocorrosion: Towards understanding interaction between biofilm and metals. Curr Opin Biotechnol 2004;15:181-6.

19. Kielemoes J, Bultinck I, Storms H, Boon N, Verstraete W. Occurrence of manganese-oxidizing microorganisms and manganese deposition during biofilm formation on stainless steel in a brackish surface water. FEMS Microbiol Ecol 2002;39:41-55.

20. Chongdar S, Gunasekaran G, Kumar P. Corrosion inhibition of mild steel by aerobic biofilm. Electrochim Acta 2005;4655-65.

21. Zuo R, Kus E, Mansfeld F, Wood TK. The importance of live biofilms in corrosion protection. Corros Sci 2005;47:279-87.

22. Acosta-Díaz S, Martín YB, González-Hernández F, TacoronteMorales JE. Evaluación de biocidas para su posible uso em depósitos de combustibles. Rev CENIC Ciências Biol 2011;42:119-23.

23. Maruthamuthu S, Mohanan S, Rajasekar A, Muthukumar N, Ponmarippan S, Subramanian P, et al. Role of corrosion inhibitor on bacterial corrosion in petroleum product pipelines. Indian $\mathrm{J}$ Chem Technol 2005;12:567-75

24. Kumar A, Fernandes J, Kumar P. Synthesis and biological evaluation of some novel schiff bases of 2-quinoline. Int J Pharm Pharm Sci 2014;6:518-21.

25. Ansari KR, Yadav DK, Ebenso EE, Quraishi M. A novel and effective pyridyl substituted 1, 2, 4-triazole as corrosion inhibitor for mild steel in acid solution. Int J Electrochem Sci 2012;7:4780-479.

26. Ebenso EE, Obot IB, Murulana LC. Quinoline and its derivatives as effective corrosion inhibitors for mild steel in acidic medium. Int $\mathrm{J}$ Electrochem Sci 2010;5:1574-86. 